\title{
The landslide database of the North-Eastern Romania
}

\author{
Mihai Niculiţă, Adrian Andrei, Cristina Lupu \\ Department of Geography, Geography and Geology Faculty \\ Alexandru Ioan Cuza University of Iaşi \\ Iaşi, Romania \\ mihai.niculita@uaic.ro, andrei_adrian9@yahoo.com, cristinalupu888@yahoo.com
}

\begin{abstract}
Landslide databases are key elements used for assessing the vulnerability and the risk associated with landslide hazard. Also these databases show us to what extent the landslides produce damages to the society, which are the most vulnerable parts and also add an important component to hazard analysis, by showing the temporal distribution of the phenomenon. Recently, this type of databases is used also for landslide rainfall initiation threshold analysis, being the base of landslide early warning systems at national and regional level.
\end{abstract}

We present a landslide database for the six counties of the North-Eastern Romania Development Region: Bacău, Botoşani, Iaşi, Neamţ, Suceava, Vaslui, covering events from 1850 to 2015. The main source for landslide information was represented by the newspapers, local, regional or national.

The database has 381 entries, 16 for Bacău County, 98 for Botoşani County, 52 for Iaşi County, 74 for Neamţ County, 78 for Suceava County and 63 for Vaslui County. The main source for the landslide events information were the local, regional and national news publications, and scientific publications and the time span of the identified landslide events is from 1900 to 2015 . Every landslide event was geolocated at least at commune level and located in time at least with the month and year. Beside the spatial and temporal localization, all the information related to the magnitude of the event (surface, volume, speed), the type of the landslide, the triggering causes, the damages that were induced to infrastructure and houses and any other information that has a meaning for landslide research.

The majority of the landslide events are reactivations, which occur from February to August, the biggest frequency periods being June-July, when heavy rainfall occurs and March-April when snowmelt and rainfall overlay. The speed of the events is small enough to allow evacuation of the population, so there was no human loess found. Beside natural causes (snowmelt and intense rainfall), there are landslides related to human activities: deforestation, road cutting, oil and gas mining. The main types of damages are related to houses and road infrastructure.

While the database is not complete, because of the different density of the sources, it is showing the general pattern of landslide reactivation and damages scenarios caused by landslides in the north-east region of Romania.
Keywords - historical landslide inventory; North-Eastern Romania; landslide hazard; landslide risk

\section{INTRODUCTION}

The landslide hazard and risk assessment requires spatial and temporal data of landslide events [1, 2, 3]. This information is given by historical sources, since the use of aerial and satellite imagery is limited to the last 60 to 80 years. While the use of remote sensing images allow us to elaborate complete landslide inventories for a limited amount of time, which in most cases is overlaid with the last climatic cycle, the historical information can be used to cover several climatic cycles, but the obtained inventory will not be complete. The historical information on landslides, in the past and today is related to events that happened in areas where society and landslides meet [3, 4]. Although not complete this type of landslide inventories are actually needed for assessing scenarios of vulnerability in order to objectively create risk scenarios $[5,6,7]$.

\section{STUDY AREA}

North-Eastern Romania Development Region covers six counties: Bacău, Botoşani, Iaşi, Neamţ, Suceava, Vaslui, and three physiographic units: Eastern Carpathians, the Moldavian Subcarpathians and the Moldavian Plateau. The population of this region is of 3.7 million people and its surface is of approx. $37000 \mathrm{~km}^{2}$. While the geology and the geomorphology of the study area is variate, the landslide triggering mechanisms are similar. Rainfall and hydrogeological water represent the main trigger, but also human activity generates landslide events.

The climate of the study area is temperate continental characterized by rainfall maximum in June-July and minimum in January-February, with mean annual temperature values ranging from -1 to $10^{\circ} \mathrm{C}$ and mean annual rainfall ranging from 1000 to $400 \mathrm{~mm}[8,9]$.

For an in depth characterization of the climate variability we have chosen to illustrate the situation of Iași city surroundings according to ROCADA dataset [9].

The daily, monthly and early rainfall data (Fig. 1) show that the 1970-1990 period was a wet period, compared with the pre 1970 and after 1990 period which 
are dry. The rainiest months are June, July, August and May. The trends for seasonal rainfall (Fig. 2) show that in the wet period (1970-1990) the winter and autumn had lower rainfall values, while the spring and summer had bigger rainfall values, compared with the dry periods. An interesting pattern is shown by the monthly heat map plot (Fig. 3), where we can see that in the wet period the rainiest yearly months slide between May and September, while in the dry period this pattern is missing.
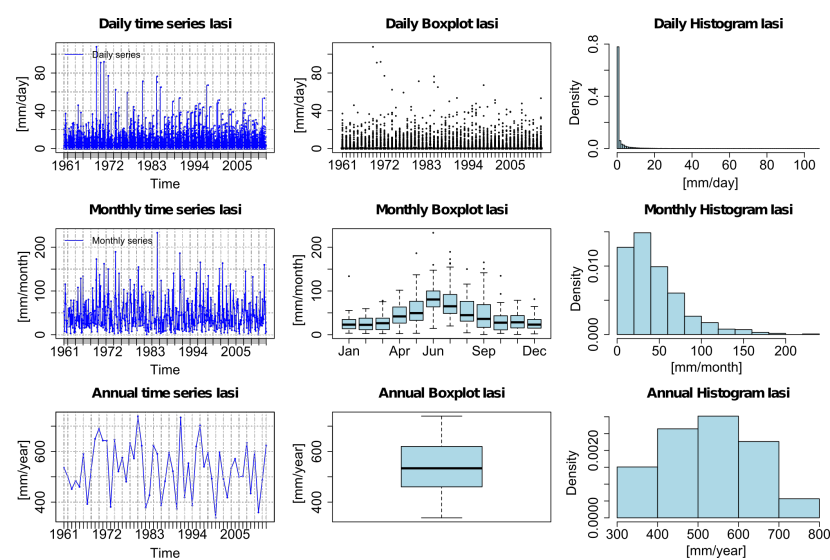

Fig. 1. Iasi surroundings daily, monthly and yearly trends of rainfall data for the 1961-2013 interval (rainfall data source: ROCADA [9])
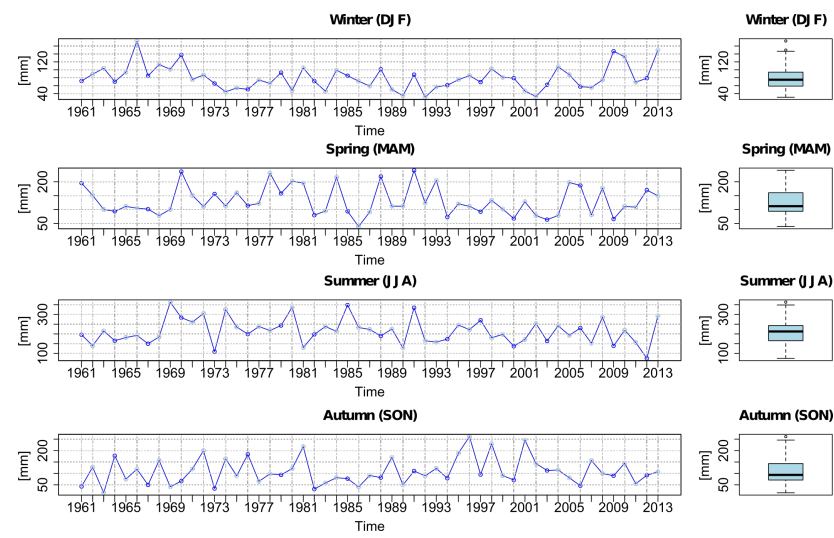

Fig. 2. Iasi surroundings seasonal trends of rainfall for the 1961-2013 interval (rainfall data source: ROCADA [9])

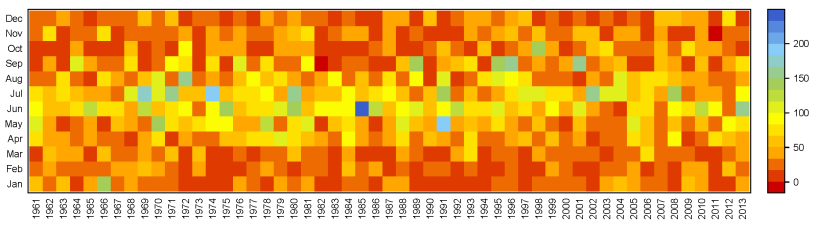

Fig. 3. Iasi surroundings monthly precipitation for the 1961-2013 interval (rainfall data source: ROCADA [9])

Spatial patterns of maximum rainfall for the study area can be seen in Fig. 4, two hot spots of maximum rainfall appearing, one in the mountainous area of Neamt and Bacău counties, and another along the Prut valley in Iași and Vaslui counties.

\section{MATERIAL AND METHODS}

The main source of landslide information varies with the time. Before 1990 the main sources are the scientific papers, or information from newspapers. After the 1990 the main source is represented by the newspapers, local, regional or national.

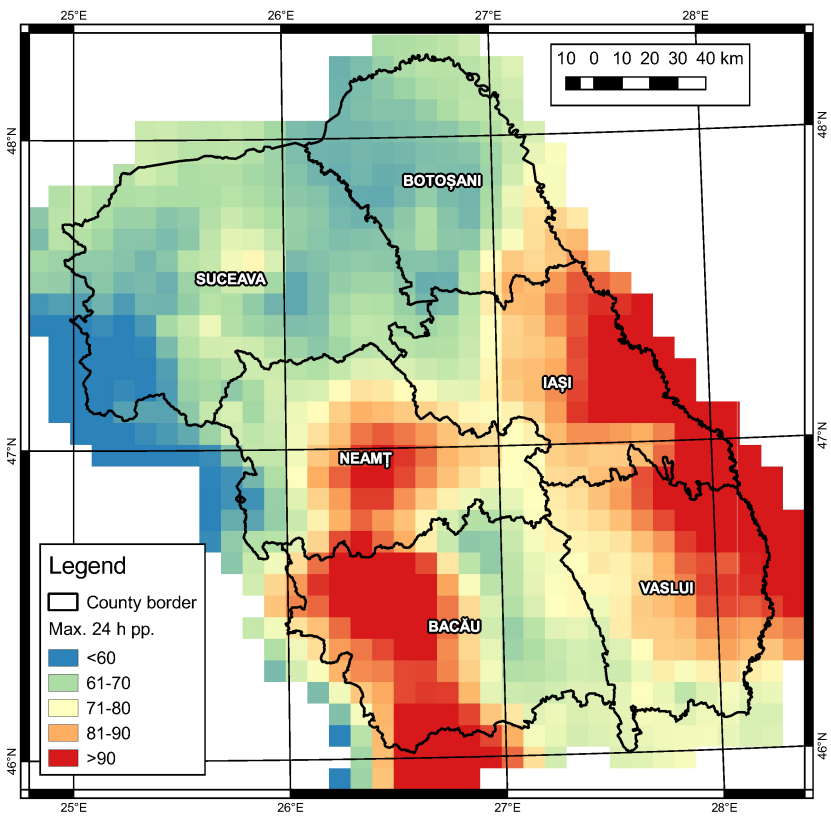

Fig. 4. Maximum precipitation in 24 hour period for the 1961-2013 interval (rainfall data source: ROCADA [9])

The database was created as an Open Office Calc sheet (Fig. 5).

\begin{tabular}{|c|c|c|c|c|c|c|c|c|c|}
\hline Date & \multicolumn{4}{|l|}{ Location } & \multicolumn{2}{|c|}{ County } & \multicolumn{2}{|c|}{ Comuna/Oras } & Siruta \\
\hline $30 / 03 / 2015$ & \multicolumn{4}{|c|}{ sat Gîteni, comuna Răcăciuni } & \multicolumn{2}{|l|}{ Bacau } & \multicolumn{2}{|c|}{ Răcăciuni } & 24766 \\
\hline $06 / 2010$ & \multicolumn{4}{|c|}{ Mărgineni, sat Valea Budului } & \multicolumn{2}{|l|}{ Bacău } & \multicolumn{2}{|c|}{ Mărgineni } & 20466 \\
\hline $1 / 04 / 2015$ & \multicolumn{4}{|c|}{ Răcăciuni, Gâsteni } & \multicolumn{2}{|c|}{ Bacă } & \multicolumn{2}{|c|}{ Răcăciuni } & 24766 \\
\hline $31 / 03 / 2015$ & \multicolumn{4}{|l|}{ Băcăciuni } & \multicolumn{2}{|l|}{ Bacău } & \multicolumn{2}{|c|}{ Răcăciuni } & 24766 \\
\hline \multirow[t]{2}{*}{2015} & \multicolumn{4}{|l|}{ Gâsteni } & \multicolumn{2}{|l|}{ Bacău } & \multicolumn{2}{|c|}{ Băcăciuni } & 24766 \\
\hline & \multicolumn{4}{|l|}{ Sesuri } & \multicolumn{2}{|l|}{ Bacău } & \multicolumn{2}{|c|}{ Măgiresti } & 23387 \\
\hline \multirow[t]{7}{*}{ Type } & Road & Length & Speed & & ume & Surt & & \multicolumn{2}{|l|}{ Damages } \\
\hline & DC 110 & & & & & & & \multicolumn{2}{|c|}{ au fost afectate 21 de lc } \\
\hline & DN 2G & & & & & & & \multicolumn{2}{|c|}{ a fost afectată conducta } \\
\hline & & & & & & & & \multicolumn{2}{|c|}{ peste 60 de persoane al } \\
\hline & & & & & & & \multicolumn{3}{|c|}{60 de persoane si-au gă } \\
\hline & & & & & & & \multicolumn{3}{|c|}{ locuinte distruse } \\
\hline & & & & & & & & \multicolumn{2}{|l|}{ sat mutat } \\
\hline
\end{tabular}

Fig. 5. A snapshot of the tabellar format of the database

The main information gathered was the temporal and the spatial localization of the landslide event. Beside this crucial information any other pertinent information that was present was registered: landslide type (Cruden and Varnes classification or it was a reactivation or new landslides if the type wasn't registered), landslide speed, landslide surface, landslide volume, affected infrastructure (building, roads, pipes), damages and the source of information.

The time resolution is variate, either a day (DD/MM/YYYY) or at least the month (MM/YYYY) or the year (YYYY). This date was registered in the start time column. If the landslide evolved more than one day, the final time column was registered, if not, the column remained unfilled.

The space resolution is variate, at least at commune level. If the information was available, the village or the precise spatial location was delineated as a polygon. The commune coding and the name were inserted. 


\section{RESUltS AND DisCUSSIONS}

The database has 381 entries, 16 for Bacău County, 98 for Botoșani County, 52 for Iaşi County, 74 for Neamţ County, 78 for Suceava County and 63 for Vaslui County. The following sources were used: newspaper and television news $(60 \%)$, public reports $(27 \%)$, urban plans (8\%), monographs and research papers (4\%) and $\mathrm{PhD}$ theses (1\%).

The majority of the landslides are reactivations, and not always the typology of the landslide can be described from the available information.

Comparing the density of the events geocoded at commune level (Fig. 6) with the spatial patterns of maximum 24 hour rainfall, we can see that there is no match. This most probably happens because of the incompleteness of the database [10].

The number of landslides per year (Fig. 7) shows a sharp increase of data availability after the 1990 and after 2000.

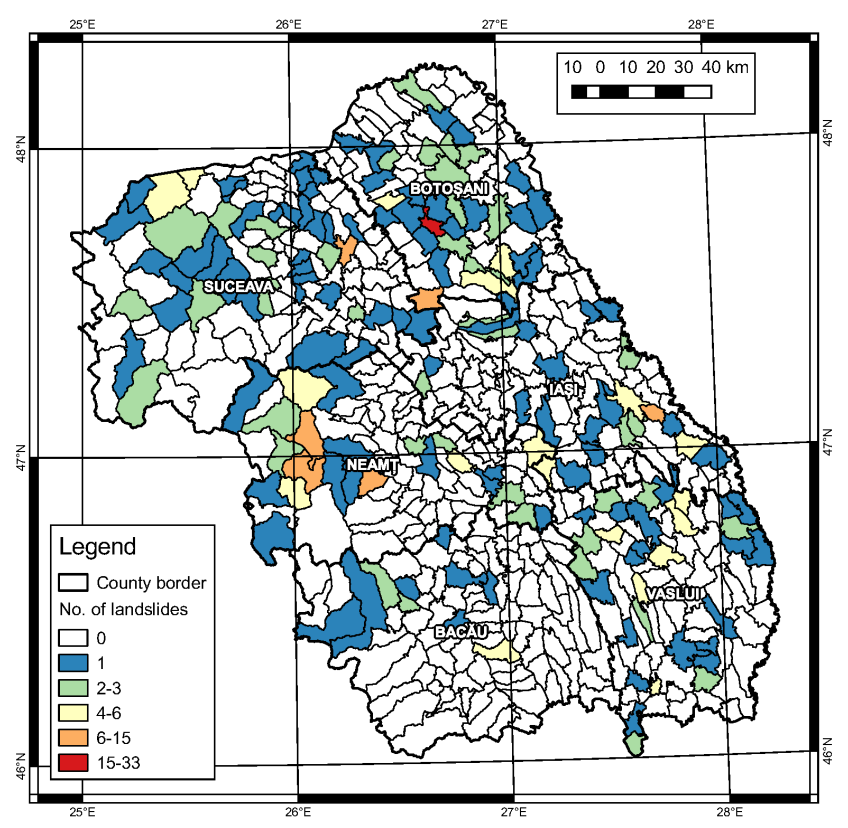

Fig. 6. The spatial distribution of landslide events, geocoded at commune level

The two most important monthly hotspots for landslide triggering are June-July and March-April. This show that the landslide mechanism in the study area in mainly related to heavy summer rainfall after wet winter and spring periods, or snowmelt and rainfall conditions met in wet springs. Late summer or autumn and winter snowmelt triggering is rare, but it happens.

Most often the reactivations strike the same area, like Botoșani city, where 33 reactivations were registered. The biggest damage was produced also by a reactivation: T,icău (Iași city neighborhood) reactivation, in which 370 houses were destroyed (12 - 13 April 1942).

The magnitudes of the landslide events of the reactivations are in general small and the landslide speed is small enough to allow safe evacuation. This is probably the explanation to the fact that no human loss was registered.
The landslides affect mostly the houses, churches, cemeteries, roads, railways (in 1992 the railway sector between Dîngeni and Săveni was affected by landslides on a sector of $100 \mathrm{~m}$, which finally because of the lack of investments generated the closure of this $53.4 \mathrm{~km}$ railway sector), industrial infrastructure (Zemeș, Bacău County landslide with a surface of 42 ha and a volume of 3 million $\mathrm{m}^{3}$, which affected 47 oil pumps and one house, triggered by the oil drilling activities) and other public infrastructure form the study area.

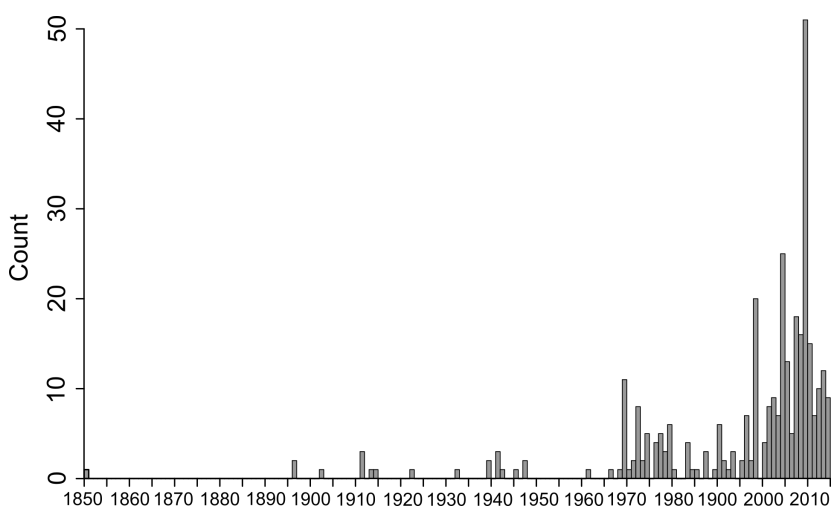

Fig. 7. Yearly landslide frequency for the study period.

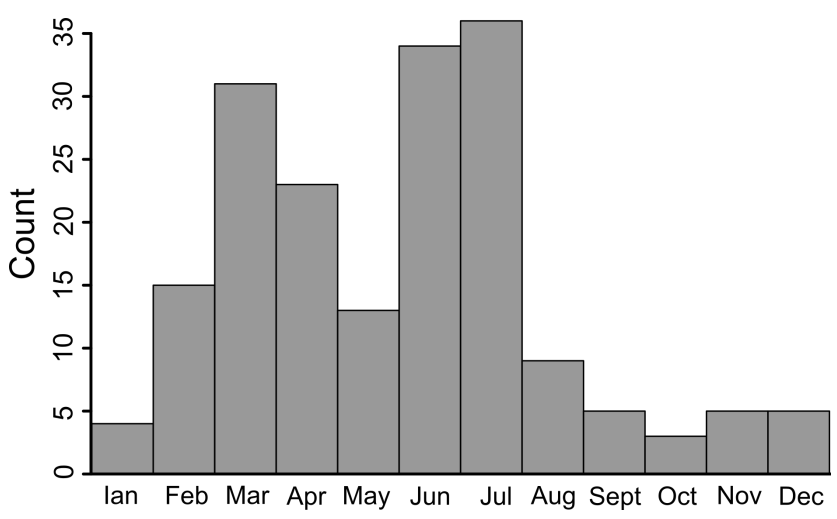

Fig. 8. Monthly landslide frequency.

Another important effect of landslide reactivation is the relocation of parts or entire villages:

- $\quad$ in 1975 Pungești village and 1978 Dragomirești, village, Vaslui County;

- $\quad$ in 1974-1975 Cîrlig village, 1996 Pârcovaci village and 1999 Todirel village, Iași County.

\section{CONCLUSIONS}

The present work represents one of the first regional historical landslide inventories, representing a lower boundary situation regarding the spatial and temporal frequency of landslides. We have identified 381 events that generated losses for houses, churches, roads, railways, industrial facilities and other infrastructure networks. No human loss was registered, mainly because of the reduced magnitude and speed of landslide events.

The main triggering factors are intense summer rainfall events and hydrogeological water related to overlaid snowmelt and rainfall, during the year two intervals are characterized by a great frequency of events: March-April and June-July. 
The majority of the recorded events are actually reactivations of old or relict landslides.

Although the database is not complete, it is usable to argue the need for an in depth analysis of past landslide events and to create vulnerability and risk scenarios. The need for further study is requested by the possible impact of future rainy periods and by the change in human pressure on hillslopes through the change in construction materials and urban/rural sprawl.

\section{REFERENCES}

[1] T. Glade, "Landslide hazard assessment and historical landslide data - an inseparable couple?,” in T. Glade, P. Albini, F. Francés, eds., The Use of Historical Data in Natural Hazard Assessments, Advances in Natural and Technological Hazards Research, vol. 17, 2001, pp. 153-168.

[2] A. Carrara, G. Crosta, and P. Frattini, "Geomorphological and historical data in assessing landslide hazard", Earth Surface Processes and Landforms, vol. 28, no. 10, pp. 1125-1142, 2003.

[3] M. Klose, Landslide databases as tools for integrated assessment of landslide risk. Springer, 156 p., 2015.
[4] D.B. Kirschbaum, A. Robert, Y. Hong, S. Hill, and A. Lerner-Lam, "A global landslide catalog for hazard applications: method, results, and limitations”, Natural Hazards, vol. 52, no. 3, pp. 561575, 2010.

[5] F. Guzzetti and G. Tonelli, "Information system on hydrological and geomorphological catastrophes in Italy (SICI): a tool for managing landslide and flood hazards”, Natural Hazards and Earth System Sciences, vol. 4, pp. 213-232, 2004.

[6] S. Pereira, J.S. Zezere, I.V. Quaresma, and C. Bateira, "Landslide incidence in the North of Portugal: analysis of a historical landslide database based on press releases and technical reports", Geomorphology, vol. 214, pp. 514-525, 2014.

[7] F. Guzzetti, C.P. Stark, and P. Salvati, "Evaluation of flood and landslide risk to the population of Italy," Environmental Management, vol. 36, no. 1, pp. 15-36, 2005.

[8] A.-E. Croitoru and Minea, "The impact of climate changes on rivers discharge in Eastern Romania”, Theoretical and Applied Climatology, vol. 120, pp. 563-573, 2015.

[9] A. Dumitrescu and M. Bîrsan, "ROCADA: a gridded daily climatic dataset over Romania (1961-2013) for nine meteorological variables”, Natural Hazards, vol. 78, no. 2, pp. 1045-1063, 2015.

[10] M. Polemio and O. Petrucci, "Occurrence of landslide events and the role of climate in the twentieth century in Calabria, southern Italy”, Quaterly Journal of Engineering Geology and Hydrogeology, vol. 43, pp. 403-415, 2010. 